\title{
ПРОБЛЕМА ИСТОРИЧЕСКИХ МИФОВ В ИССЛЕДОВАНИЯХ ИСТОРИЧЕСКОЙ ШКОЛЫ МОСКОВСКОГО ГУМАНИТАРНОГО УНИВЕРСИТЕТА И РАБОТЫ Б.А. РУЧКИНА
}

\author{
С. В. Алексеев \\ (Московский гуманитарный университет)
}

\begin{abstract}
Аннотация: Темой статьи является опыт исследований исторической школой Московского гуманитарного университета проблемы исторического мифа в ее теоретическом и конкретном измерениях. Тема «Демифологизация истории России» является ключевой в разработках исторической школы университета, работающих в нем ведущих специалистов-историков применительно $к$ различным историческим периодам. Ключевой вклад в работу по исследованию различных аспектов исторической мифологии, процессов мифологизации и демифологизации истории на протяжении ряда лет внес директор Центра исторических исследований Института фундаментальных и прикладных исследований Московского гуманитарного университета, доктор исторических наук, профессор Б.А. Ручкин (1936-2015).
\end{abstract}

Ключевые слова: история; исторические мифы; исторические фальсификации; историческое сознание; историография; историческая школа Московского гуманитарного университета; Б.А. Ручкин; Московский гуманитарный университет

\section{THE PROBLEM OF HISTORICAL MYTHS IN THE STUDIES BY THE HISTORICAL SCHOOL OF MOSCOW UNIVERSITY FOR THE HUMANITIES AND THE WORKS OF B.A. RUCHKIN}

\author{
S. V. Alekseev \\ (Moscow University for the Humanities)
}

\begin{abstract}
The article examines the experience of the historical school of Moscow University for the Humanities in studying historical myths in their theoretical aspects and practical forms. The university's leading historians focus on various fields and periods, but the problem of demythologization of the history of Russia remains the centerpiece of the development of the university's historical school. A key contribution to the study of various aspects of historical mythology, mythologizing and demythologizing of history has been made over the years by an outstanding representative of the historical schoolof the University, director of the Center for Historical Research of the Institute of Fundamental and Applied Studies of Moscow University for the Humanities, Doctor of History, Professor B.A.Ruchkin (1936-2015).
\end{abstract}

Keywords: History; historical myths; historical falsifications; historical consciousness; historiography; historical school of the Moscow University for the Humanities; B.A.Ruchkin; Moscow University for the Humanities 
На протяжении последних десятилетий все более существенное место в исследованиях научных школ Московского гуманитарного университета, прежде всего исторической, занимает тема исторического мифа, фальсификаций истории, возможных путей и перспектив демифологизации истории России. Важнейший вклад в разработку этой темы внес инициировавший ее исследование ректор Московского гуманитарного университета профессор И.М. Ильинский. Им подготовлен ряд работ, посвященных демифологизации истории Великой Отечественной войны (Ильинский, 2010, 2014ab). Под руководством И.М. Ильинского Центром образовательных технологий при поддержке Общества «Знание» России осуществлен в 2013-2014 гг. научный проект «Демифологизация истории России».

Исторические мифы, механизмы их возникновения, пути изживания являются уже традиционной темой работ специалистов кафедры истории Московского гуманитарного университета. В рамках этой темы создавались работы, посвященные различным периодам истории России: Древней Руси (Алексеев, 2005), XVIII веку (Елисеева, 2013, 2014). Главной же темой исследований являлись проблемы российской истории ХХв. В рамках проекта «Демифологизация истории России» специалистами кафедры подготовлен ряд глав коллективной монографии «Россия. XX век. История. Мифы. Память» (Россия ..., 2014).

Одним из инициаторов и активнейшим участником разработки темы мифологизации и демифологизации истории в рамках исторической школы Московского гуманитарного университета стал доктор исторических наук, профессор Борис Александрович Ручкин (9.01.1936-2.06.2015), директор Центра исторических исследований Института фундаментальных и прикладных исследований МосГУ. Крупный исследователь истории молодежного движения, социальных проблем молодежи, молодежного сознания, к теме исторической мифологии Б.А. Ручкин активно обращался с 2011 г. В этом же году вышли статья, посвященная теоретическим и практическим аспектам анализа исторических мифов (Ручкин, 2011: Электр.ресурс) и раздел в соавторской монографии (Криворученко, Ручкин, 2011).

Значительное место в работах Б.А. Ручкина традиционно занимал прошедший на его глазах и при его участии последний период деятельности ВЛКСМ. Анализируя процессы, протекавшие в основной молодежной организации СССР, исследователь неизбежно касался и окружившей комсомол в последние десятилетия исторической мифологии. Это касалось как общих вопросов истории ВЛКСМ (Ручкин, 2013ab: Электр.ресурс), так и судеб комсомольских работников после роспуска организации (Ручкин, 2013с: Электр.ресурс), или такого известного (в том числе и по многочисленным домыслам) дела комсомола, как строительство Байкало-Амурской магистрали (Королев, Ручкин, 2013). 
Б.А. Ручкин принял активное участие в реализации исследовательского проекта «Демифологизация истории России». В рамках его он сосредоточился на теме мифологем, связанных с историей Великой Отечественной войны (Ручкин, 2014а). Другим избранным им направлениям исследования стал анализа перспектив единого учебника отечественной истории, которые Б.А. Ручкин оценивал весьма критично - как в плане самой идеи, так и с точки зрения содержания опубликованной концепции. Этой теме посвящена подробные статьи (Ручкин, 2014bc: Электр.peсурс) и одна из глав вышеназванной коллективной монографии.

Б. А. Ручкин стал одним из инициаторов исследовательского проекта «Влияние исторических фальсификаций и мифов на сознание и социальное поведение современной российской молодежи». В последнем соединились усилия специалистов кафедры истории и Института фундаментальных и прикладных исследований Московского гуманитарного университета, исторической и социологической научных школ. Проект был поддержан фондом «Институт социально-экономических и политических исследований» (ИСЭПИ) в рамках Президентской программы поддержки НКО. Проводилось исследование в 2014-2015 гг. Оно включало опрос экспертов, эмпирическое исследование исторической осведомленности молодежи, а также анализ теоретических аспектов заявленной темы.

Б.А. Ручкин внес ощутимый вклад в разработку теоретических аспектов исследования. В рамках проекта Б.А. Ручкин руководил проведением экспертного опроса (Алексеев, Плотникова, Ручкин, 2015ab: Электр. ресурс).В октябре-декабре 2014 г. было опрошено 30 экспертов - специалистов, работающих с молодежью, и исследователей проблем молодежи. В соответствии с утвержденной на первом этапе проекта методикой отбора участников, для опроса отбирались представители следующих групп экспертов: 1) специалисты по проблемам молодежи; 2) специалисты, работающие с молодежью; 3) историки-преподаватели и молодые историки. Настоящее деление, естественно, является отчасти условным. Среди специалистов по молодежной проблематике имеются профессиональные историки; среди опрошенных руководителей высших учебных заведений и их подразделений имеются специалисты-ювенологи и историки.

При отборе экспертов был использован богатый потенциал научной школы Московского гуманитарного университета (в прошлом - Высшей комсомольской школы) - старейшего центра ювенологических исследований в России, на базе которого реализуется настоящий проект. В то же время, в соответствии с принципами опроса, привлекались специалисты из различных организаций и учреждений Москвы, а также российских регионов. С целью максимально большего охвата мнений по заявленной проблематике к опросу были привлечены специалисты из Орла, 
Тулы, Саратова, Петрозаводска. Опрашивались представители системы как высшего, так и среднего образования, общественных организаций, работающие с молодежью руководители и представители общественных организаций, средств массовой информации. Экспертный состав представляется адекватным заявленным целям исследования.

Анкета эксперта включала 18 вопросов. Первые вопросы (1-2) были призваны определить восприятие экспертами общего состояния современной молодежи и взаимоотношений молодежи и власти. Последующие вопросы (3-8) требовали от респондентов оценить современное состояние патриотизма в молодежной среде и патриотического воспитания, место истории в воспитании патриотизма. Вопросы 9-15 и 17 были посвящены основной теме исследования. Экспертам предлагалось определить соотношение мифов и фальсификаций в молодежном сознании, выделить наиболее значимые составляющие исторической мифологии и мифотворчества, оценить их влияние на молодежное сознание. Вопросы 16 и 18 призваны были определить взгляд экспертов на концепцию преподавания отечественной истории - круг необходимых, по их мнению, для изучения исторических событий и отношение к существующей концепции единого учебника истории.

По итогам проведения экспертного опроса был подготовлен аналитический материал.Подводя итоги опроса, можно отметить, что почти все эксперты согласились с мнением о необходимости усилить историческое воспитание молодежи - как часть воспитания гражданина и патриота. Проблема эта, и по нашему мнению, остро стоит на повестке дня. Однако на пути ее решения - ряд проблем, на многие из которых указывали и опрошенные эксперты.

Проведенный опрос студенческой молодежи г. Москвы выявил уровень знания истории - но не исторического сознания. Между тем, последнее включает целую совокупность взаимосвязанных элементов: знание истории, осмысление исторического опыта и вытекающих из него уроков, социальное прогнозирование, осознание исторической ответственности за свою деятельность. Историческое сознание, как отдельного человека, так и группы лиц очень сложно выявить. Но наша сегодняшняя молодежь, да и общество в целом, этим сознанием точно не обладает, в отличии от некоторого знания истории. С этой точки зрения критичность большей части оценок экспертного сообщества вполне обоснована.

Анализ результатов экспертного опроса побудил Б.А. Ручкина подробнее остановиться на теме патриотизма. В целом, по мнению экспертов, проявления патриотизма стали существенно заметнее в сравнении с показателями эпохи социальной неопределенности. Пик подъема патриотизма приходится на 2014 г. - год огромных внешнеполитических 
успехов. Вместе с тем исследователи, политологи, социологи, в большинстве своем сходятся на том, что патриотическая консолидация 2014 г. не носит долговременный характер. Обостряют проблемы патриотического воспитания кризисные явления в экономике, санкции, «война без войны» и многое другое создают качественно иной фон всей общественной жизни. Главное - слабость одержанных успехов основывается на зыбкости их экономического фундамента. Власть реально оценивает существующие риски и принимает энергичные антикризисные меры. И в этой связи патриотизм как мобилизационный проект призван способствовать быстрому развитию страны. Стабилизирующим фактором сегодня является огромный авторитет Президента РФ, национального лидера большинства россиян, призвавшего строить свое будущее на прочном фундаменте - патриотизме. Эти выводы были сформулированы Б.А. Ручкиным в специальной статье (Ручкин, 2015а) и докладе на круглом столе «Влияние исторических фальсификаций и мифов на сознание и социальное поведение современной российской молодежи» (Ручкин, 2015b).

Борис Александрович Ручкин скончался 2 июня 2015 г. Материалы, подготовленные им, вошли в итоговую коллективную монографию, посвященную историческому сознанию молодежи (Историческое сознание, 2015). Неоконченным осталось исследование мемуаров полководцев Великой Отечественной войны, предпринятое ученым как часть анализа мифов и фальсификаций о военном времени.

Работы Б.А. Ручкина внесли фундаментальный вклад в разработку тематики исторической мифологии научной школой университета. Теоретические выводы, содержащиеся в них, обширный фактический материал используется другими исследователями. Тема мифологизации и демифологизации отечественной истории продолжает оставаться одной из центральных в работе исторической школы университета.

\section{СПИСОК ЛИТЕРАТУРЫ}

Алексеев, С. В. (2005) Литературные и археологические источники о крещении Новгорода // Знание. Понимание. Умение. № 2. С. 185-195.

Алексеев, С. В., Плотникова, О. А., Ручкин, Б. А. (2015а) Экспертный опрос «Влияние исторических фальсификаций и мифов на сознание и социальное поведение современной российской молодежи»: общая информация [Электронный ресурс] // Информационный гуманитарный портал «Знание. Понимание. Умение». № 1.URL: http://www.zpu-journal.ru/ezpu/2015/1/Alekseev_Ruchkin_Plotnikova_Falsifications-Myths-Youth/ (дата обращения: 12.09.2015).

Алексеев, С. В., Плотникова, О. А., Ручкин, Б. А. (2015b) Экспертный опрос «Влияние исторических фальсификаций и мифов на сознание и социальное поведение современной российской молодежи»: анализ ре- 
зультатов [Электронный ресурс] // Информационный гуманитарный портал «Знание. Понимание. Умение». № 1. URL: http://www.zpu-journal. ru/e-zpu/2015/1/Alekseev_Ruchkin_Plotnikova_Falsifications-Myths-YouthResults/ (дата обращения: 12.09.2015).

Елисеева, О. И. (2013) Игры памяти. Проблема исторической достоверности в «Записках» Е.Р. Дашковой // Историческое обозрение. Вып. 14. С. 50-57.

Елисеева, О. И. (2014) Сентиментальный экзекутор // Научные труды Московского гуманитарного университета. № 9. С. 16-46.

Ильинский, И. М. (2010) Это наша Победа. Точка. М.: Московский гуманитарный университет. 27 с.

Ильинский, И. М. (2014а) Живу и помню. М.: Московский гуманитарный университет. 232 с.

Ильинский, И. М. (2014b) Великая Отечественная: правда и факты против мифов. М.: Московский гуманитарный университет. 180 с.

Историческое сознание российской молодежи (2015). М. : Московский гуманитарный университет. 115 с.

Королев, А. А., Ручкин, Б. А. (2013) БАМ: уроки истории // Знание. Понимание. Умение. № 3. С. 136-143.

Криворученко, В. К., Ручкин, Б. А. (2011) Историческая наука: проблемы развития. М. : Национальный институт бизнеса. 276 с.

Россия. ХХ век. История. Мифы. Память (2014). М. : Московский гуманитарный университет. 144 с.

Ручкин, Б. А. (2011) Проблема «Мифы и история». Историческое обозрение [Электронный ресурс] // Информационный гуманитарный портал «Знание. Понимание. Умение». № 1. URL: http://www.zpu-journal.ru/ezpu/2011/1/Ruchkin_Myths/ (дата обращения: 12.09.2015).

Ручкин, Б. А. (2013а) ВЛКСМ - непознанное наследие [Электронный ресурс] // Информационный гуманитарный портал «Знание. Понимание. Умение». № 4. URL: http://www.zpu-journal.ru/e-zpu/2013/4/Ruchkin_ VLKSM-Unexplored-Legacy/ (дата обращения: 12.09.2015).

Ручкин, Б.А. (2013b) Книги о комсомоле [Электронный ресурс] // Информационный гуманитарный портал «Знание. Понимание. Умение». № 4. URL: http://www.zpu-journal.ru/e-zpu/2013/4/Ruchkin_Books-Komsomol/ (дата обращения: 12.09.2015).

Ручкин, Б. А. (2013c) Комсомольская элита и становление бизнескласса [Электронный ресурс] // Информационный гуманитарный портал «Знание. Понимание. Умение». № 4. URL: http://www.zpu-journal. ru/e-zpu/2013/4/Ruchkin_Komsomol-Business-Class/ (дата обращения: 12.09.2015).

Ручкин, Б. А. (2014а) 1941-й: миф «Армия не воевала» (историческое 
обозрение) // Знание. Понимание. Умение. № 2. С. 125-130.

Ручкин, Б. А. (2014b) Новый учебник истории: новая мифология [Электронный ресурс] // Информационный гуманитарный портал «Знание. Понимание. Умение». № 4.URL: http://www.zpu-journal.ru/e-zpu/2014/4/ Ruchkin_New-Textbook-History-Mythology/ (дата обращения: 12.09.2015).

Ручкин, Б. А. (2014c) Новый учебник истории: ориентир государственной идеологии [Электронный ресурс] // Информационный гуманитарный портал «Знание. Понимание. Умение». № 5. URL: http://www.zpu-journal. ru/e-zpu/2014/5/Ruchkin_New-Textbook-History-Ideology/ (дата обращения: 12.09.2015).

Ручкин, Б. А. (2015a) Российское общество: патриотизм XXI века // Знание. Понимание, Умение. № 1. С. 52-70.

Ручкин, Б. А. (2015b) Российское общество: патриотизм XXI века в зеркале экспертного опроса // Историческое обозрение. Вып. 16. С. 34-39.

Алексеев Сергей Викторович - доктор исторических наук, профессор,заведующий кафедрой истории Московского гуманитарного университета, председатель Историко-Просветительского общества «Радетель», главный редактор альманаха «Историческое обозрение». Адрес: 111395, Россия, г. Москва, ул. Юности, д. 5. Тел.: +7 (499) 374-55-81. Эл. адрес: ipo1972@mail.ru

Alekseev Sergey Viktorovich, Doctor of History, Professor and Chair, Department of History, Moscow University for the Humanities; Chairman, 'Radetel' Historical and Educational society; Editor-in-Chief, Historical Review. Postal address: 5 Yunosti St., 111395 Moscow, Russian Federation. Tel.: +7 (499) 374-55-81.E-mail:ipo1972@mail.ru 